\title{
NEW TERRITORIAL DEVELOPMENT TOOLS IN THE COHESION POLICY 2014-2020
}

\section{Györgyi NYIKOS, Dr.}

Corvinus University of Budapest

Address: $\quad$ H-1093 Budapest, Fővám tér 8.

E-mail: $\quad$ gyorgyi.nyikos@gmail.com 
Nyikos, G.

\title{
New territorial development tools in the Cohesion Policy 2014-2020
}

Keywords: territorial development, sustainable integrated approach, cohesion policy, ITI, and CLLD

\begin{abstract}
:
Nowadays an important question is how to use the limited resources available in the most efficient and sustainable way. The assessment of development policy interventions and the question of successful absorption of development funds shifted clearly towards stronger enforcement of the aspects efficiency and effectiveness. There is clearly a need for an integrated approach to deliver an effective and sustainable response. The question is how the new territorial development tools - established by the new cohesion policy regulation for the coming programming period - can fit in these conditions, how can they help to achieve the common goals and response to the integrated approach. Cooperation and in-depth knowledge is required for stakeholders to make use of the new tools in an integrated manner.
\end{abstract}

\section{INTRODUCTION}

In the cohesion policy the general regulation for 2014-2020 (CPR $)^{22}$ set off new territorial development instruments proposed for the coming programming period and via these tools European subsidies from different EU funds can be combined. The question is how the new territorial development tools can help to achieve the common goals and respond to the integrated approach.

\section{OBJECTIVES AND METHODS}

The overarching objective of European cohesion policy is to promote the harmonious development of the union and its regions and as a "new" objective - since the Lisboan Treaty - cohesion policy should also promote more balanced, more sustainable "territorial development", which seems to be a broader concept than the traditional regional policy.

The efficiency of public spending has been an important issue throughout the course of history, and in the current economic and financial climate, the questions of on what and how the scarce resources available are spent, and what the impact of this spending is are of particular importance. In connection with the development-oriented utilization of funds, it is of fundamental importance whether the use of public funds is justified, which areas require development and where the best result can be ensured (value for money

\footnotetext{
${ }^{22}$ REGULATION (EU) No 1303/2013 OF THE EUROPEAN PARLIAMENT AND OF THE COUNCIL of 17 December 2013 laying down common provisions on the European Regional Development Fund, the European Social Fund, the Cohesion Fund, the European Agricultural Fund for Rural Development and the European Maritime and Fisheries Fund and laying down general provisions on the European Regional Development Fund, the European Social Fund, the Cohesion Fund and the European Maritime and Fisheries Fund and repealing Council Regulation (EC) No 1083/2006
} 
principle $)^{23}$. In the next 2014-2020 period an important question is how to use the limited resources available in the most efficient and sustainable way, especially the sources aimed for development. Improving efficiency and effectiveness of public spending is required by the Stability and Growth Pact, but it is also instrumental to ensure progress towards the agreed goals of the EU2020 Strategy. The assessment of development policy interventions and the question of successful absorption of development funds shifted clearly towards stronger enforcement of the aspects efficiency and effectiveness. So on one hand, fiscal stability must be preserved and public deficit contained. On the other hand the foundations of economic progress must be laid down and the economy must be put on a fast lane of expansion, but the main difficulty of this task is to execute these measures simultaneously.

The multiple challenges confronting Europe - economic, environmental and social show the need for an integrated and territorial place-based approach to deliver an effective response. As a response to this fact one of the key elements of the reform is using the integrated approach to increase efficiency with establishing new integrating tools such as a common strategy or new territorial development tools (Integrated Territorial Investment (ITI), Community-led Local Development (CLLD)) or Joint Action Plan (JAP) for more coordination and less overlaps. An integrated approach is multi-dimensional, which may mean going beyond traditional administrative boundaries, and may require greater willingness from different levels of government to co-operate and co-ordinate actions in order to achieve shared goals.

The present paper explores the legislation on these new territorial development instruments proposed for the coming programming period and respond to the question, if these tools can be able in the praxis to achieve of the smart, sustainable and inclusive Europe envisaged by the Europe 2020 Strategy. The paper uses sources of information based on desk research (studies, evaluations, official documents and adopted regulations) and experiences from managing and implementing operational programs and projects.

\section{RESULTS AND DISCUSSION}

EU Cohesion Policy 2014-2020 shall contribute to the EU 2020 Strategy of a smart, sustainable and inclusive growth. This is the challenge for the new period. Policy makers shall even more in the current economic climate deliver results which are based on

\footnotetext{
${ }^{23}$ Györgyi Nyikos (2013): The impact of developments implemented from public finances, with special regard to EU cohesion policy, Public Finance Quarterly, Journal of public finance, 2013/2 165-185. pp.
} 
evidence in order to ensure the most efficient spending of funds. The European Union has since the programming for 2007-2013 added the objective of territorial cohesion and is opting for an integrated, place-based approach. Territorial cohesion is a positive concept and definable as the territorial dimension of sustainability and more specifically as the "ordered, resource efficient, environmental-friendly spatial distribution of human activities". The three main components of territorial cohesion:

- territorial quality (corresponds to the social dimension of sustainability quality of life and good working conditions for all as well as bridging the gap between the knowledge-rich and the knowledge-poor);

- territorial efficiency (is understood as an efficiency of natural resources, competitiveness and local attractiveness, corresponds to the environmental aspect of sustainability) and

- territorial identity (is articulating the concept of social capital, local know-how, tacit knowledge and the local competitive advantage, is the equivalent of the economic angle of sustainability)

Territorial cohesion as an EU project thus seeks to:

- achieve greater outcome effectiveness of EU social, economic and environmental interventions;

- achieve greater resource efficiencies in EU social, economic and environmental interventions;

- promote changes in governance to address changing EU wide spatial forms of economic, social and environmental developments;

- address EU wide inequalities that underlie territorial diversity and differences;

- provide a rationale for a future EU 'integrated place-based' cohesion policy.

The challenge, however, remains on how to implement sustainable development in practice; how to modernize the European economy and raise living standards while respecting the environment and promoting social and territorial cohesion.

Cohesion policy in general is deemed to be a unique instrument which allows for the reconciliation of:

- different types of - sectoral - objectives and aspects of development (e.g. social, environmental, infrastructural, economic aspects etc.),

- different levels of governance (at the EU, Member State, region or local level), but there is still the necessity of using special tools proposed for the integrated approach and the management of territorial aspects. Cohesion policy is namely also the policy 
behind the thousands of projects all over Europe that receive funding from different funds. In the new regulation the Common Strategic Framework (CSF) include European Regional Development Fund (ERDF) ${ }^{24}$, European Social Fund $(\mathrm{ESF})^{25}$, Cohesion Fund $(\mathrm{CF})^{26}$, European Agricultural Fund for Rural Development (EAFRD) ${ }^{27}$ and the European Maritime and Fisheries Fund (EMFF). Each and one of these are conceived to have a thematic scope, also indicated by its title. However the new regulation in response to the integrated approach offers the possibility to common use of the funds addressing the Common Strategic Framework. This means that a project which tackles a complex situation, such as structural interventions in different aspects and themes, may be funded by different sources coming from different operational programmes. The question is that how to address the complex situations, the territorial challenges in the programming process: one solution could be to use multifund regional operational programmes and manage them at the regional level, the other or additional possibility is using common planning instruments which allow to manage territorial challenges at territorial - macroregional, regional or micro-regional - level. Some of these tools are total new like the Integrated Territorial Investment (ITI), other instruments are rather a new generation of existing practices, like the Community-led Local Development, which is based on the LEADER approach.

Integrated territorial investments (ITI) ${ }^{28}$ are a tool to implement territorial strategies in an integrated way, allowing Member States to implement Operational Programmes in a cross-cutting way and to draw on funding from several priority axes of one or more Operational Programmes to ensure the implementation of an integrated strategy for a specific territory, especially supporting sustainable urban development in the cities. It is important to underline that ITIs can only be effectively used if the specific geographical area concerned has an integrated, cross-sectoral territorial strategy - it is a mechanism for the set-up of flexible "sub-programmes". Accordingly using ITIs can be necessary where the implementation of the territorial strategy requires integrated investment from more than

\footnotetext{
${ }^{24}$ REGULATION (EU) No 1301/2013 OF THE EUROPEAN PARLIAMENT AND OF THE COUNCIL of 17 December 2013 on the European Regional Development Fund and on specific provisions concerning the Investment for growth and jobs goal and repealing Regulation (EC) No 1080/2006

${ }^{25}$ REGULATION (EU) No 1304/2013 OF THE EUROPEAN PARLIAMENT AND OF THE COUNCIL of 17 December 2013 on the European Social Fund and repealing Council Regulation (EC) No 1081/2006

${ }^{26}$ REGULATION (EU) No 1300/2013 OF THE EUROPEAN PARLIAMENT AND OF THE COUNCIL of 17 December 2013 on the Cohesion Fund and repealing Council Regulation (EC) No 1084/2006

${ }^{27}$ REGULATION (EU) No 1305/2013 OF THE EUROPEAN PARLIAMENT AND OF THE COUNCIL of 17 December 2013 on support for rural development by the European Agricultural Fund for Rural Development (EAFRD) and repealing Council Regulation (EC) No 1698/2005

${ }^{28}$ CPR. Art. 36.
} 
one priority axis (or operational programme) in a coordinated manner. There are also alternatives to ITI to address this kind of situations in the "toolkit" provided, for examples a specific OP, integrated operations, "multi-investment-priority" priority axes.

Figure 1 ITI structure (Source: European Commission, SAWP Meeting, 3 July 2012)

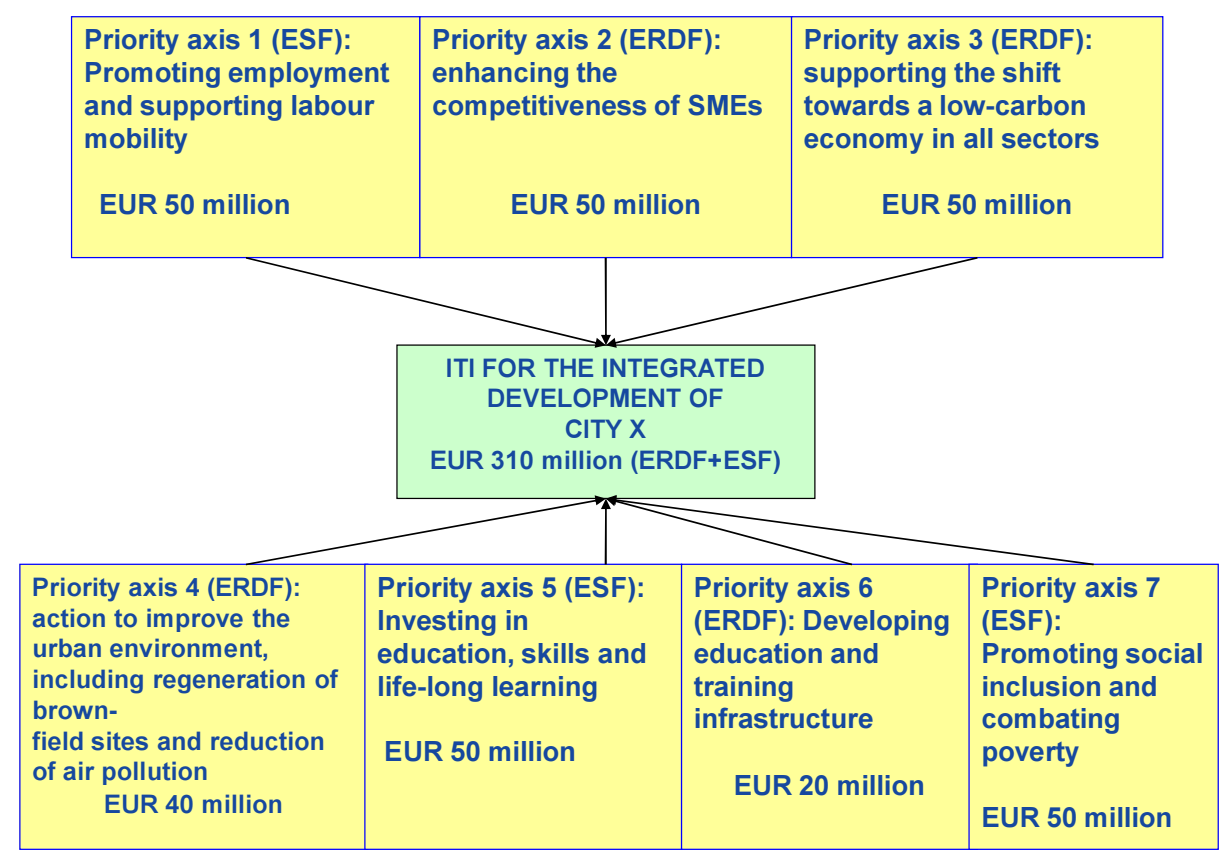

The key elements of an ITI are:

- a designated territory and an integrated territorial development strategy;

- a package of actions to be implemented;

- $\quad$ and governance arrangements to manage the ITI.

Cities are considered the main potential beneficiaries of this tool as ITI enables them to plan and implement comprehensive development programmes for the use of funds belonging to different priorities of ERDF, European Social Fund (ESF) or other Common Strategic Framework funds to implement innovative actions that have social, environmental and development objectives. ITI can also promote the allocation of more responsibility to the various multi-level governance stakeholders, because ITI implementation tasks can be delegated to any competent legal entity, to the municipality or any other appropriate territorial entity concerned. ITI can be set-up both at the beginning and during the programming period. 
Community-led Local Development $(\mathrm{CLLD})^{29}$ is a specific tool for use at sub-regional level, which is carried out through integrated and multi-sectoral area-based local development strategies and allows the integrated use of the funds. This local development approach is obligatory for EAFRD and optional for ERDF, ESF and EMFF.

The main aims of CLLD are:

- to encourage local communities to develop integrated bottom-up approaches in circumstances where there is a need to respond to territorial and local challenges calling for structural change

- build community capacity and stimulate innovation (including social innovation), entrepreneurship and capacity for change by encouraging the development and discovery of untapped potential from within communities and territories

- promote community ownership by increasing participation within communities and build the sense of involvement and ownership that can increase the effectiveness of EU policies

- assist multi-level governance by providing a route for local communities to fully take part in shaping the implementation of EU objectives in all areas.

The CLLD's main beneficiary will be the Local Action Group (LAG) ${ }^{30}$ and the development strategy for the territory must be established through a bottom-up approach. The selection criteria for local development strategies are defined by the memberstate with three options for delivery:

- joint funding

1. one area-one strategy,

2. integrated funding for functional areas

- mono-funding

3. one area - one fund

If the local development strategy requires multi-fund support a "lead fund" can be designated according to the activities foreseen and the area in question. Management costs of LAGs are reimbursed through the lead fund. The selection criteria for LAGs should be defined at national level taking into account the content of the delegated act and existing local development structures and processes. The CPR contains the minimum tasks to be delegated to LAGs, and even full delegation of tasks is also possible: LAG can be an intermediate body as well. All in all CLLD is also a coordination mechanism at national or

\footnotetext{
${ }^{29}$ CPR. Art. 32-35.

${ }^{30}$ CPR. Art. 34.
} 
regional level covering several European Structural and Investment Funds: required involving all relevant management authorities (set up joint monitoring committee for CLLD is an optional possibility) and also possible further coordination using specific/ joint intermediate body for CLLD at sub-national level.

In the programming process the following information have to be provided in the programmes: principles for the identification of the areas in which CLLD will be implemented; description of the selection, approval and funding arrangements of the local development strategies (LDS) and local action groups (LAG): main eligibility criteria and types of support and the indicative financial allocation for support to CLLD by the fund in question.

Figure 2 CLLD structure (Source: European Commission, Seminar on community-led local development, 6 February 2013 )

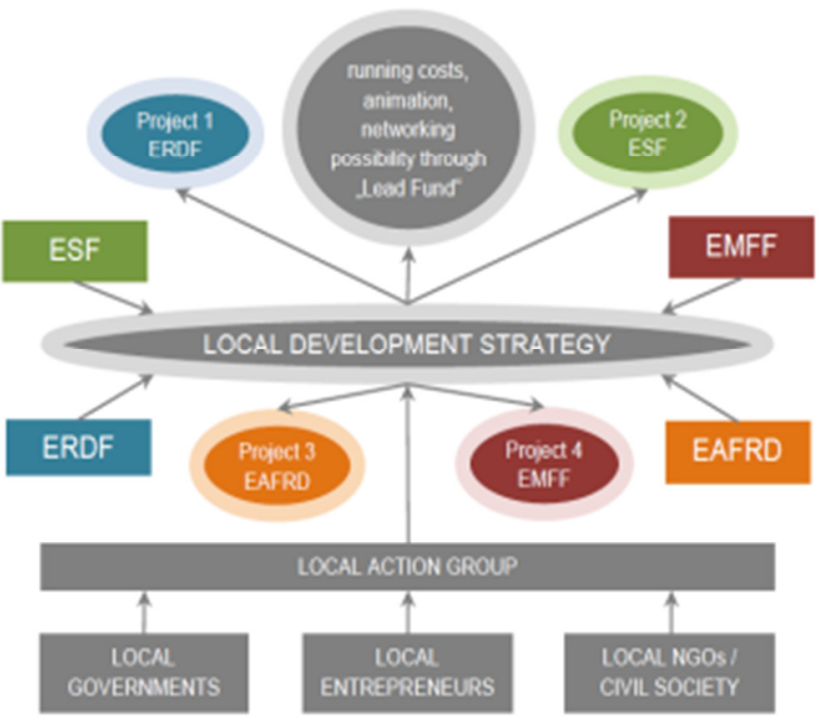

Both new instruments can also be used for supporting an integrated territorial approach, but there are some limitations: firstly the integrated territorial approach and the use of the two new territorial instruments is only highlighted in relation to either urban (ITI) or rural areas (CLLD) and in the case of mixed-natured arias there is a need for some clarification.

Figure 3 Joint funding examples 


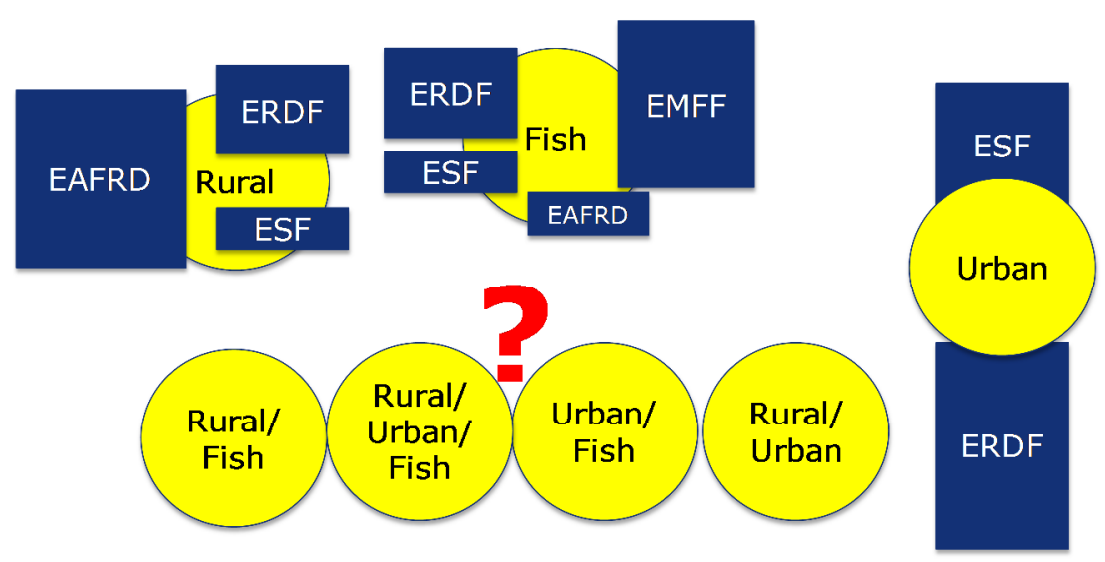

Secondly the CLLD instrument is mainly targeted to smaller (functional) territories with a limited population (either urban neighbourhoods or rural areas) as well as small-scale projects. Moreover, the implementation is highly community driven, which could bring institutional and legal restrictions for decisions on investments and for larger functional regions.

Figure 4 Main features (ITI, CLLD)

\begin{tabular}{|c|c|c|}
\hline & ITI & CLLD \\
\hline nature & implementation method & development approach \\
\hline $\begin{array}{l}\text { related } \\
\text { strategy }\end{array}$ & $\begin{array}{l}\text { not compulsorily required by law; } \\
\text { tool to facilitate the implementation of } \\
\text { existing regional strategies }\end{array}$ & local development strategy required \\
\hline territorial level & not specified in the regulation & $\begin{array}{l}\text { compulsorily below regional level, } \\
\text { local level } \\
\text { even cross-border region (national } \\
\text { competence) }\end{array}$ \\
\hline sources & ERDF, ESF, CF, EAFRD & $\begin{array}{c}\text { ERDF, ESF, CF, EAFRD, EMFF } \\
\text { by multi-fund support a lead fund can } \\
\text { be designed }\end{array}$ \\
\hline $\begin{array}{l}\text { institutional } \\
\text { provision }\end{array}$ & $\begin{array}{l}\text { possible designation of one or more IB; } \\
\text { implementation can be delegated }\end{array}$ & $\begin{array}{l}\text { compulsory to create local action } \\
\text { groups; } \\
\text { creation of specialized committees to } \\
\text { approve the strategies with the } \\
\text { involvement of the MAs }\end{array}$ \\
\hline imposition & optional & $\begin{array}{c}\text { optional (except in the case of rural } \\
\text { development) }\end{array}$ \\
\hline incentive & $\begin{array}{c}\text { at least } 5 \% \text { of the national ERDF shall be } \\
\text { allocated to actions for sustainable urban } \\
\text { development }\end{array}$ & $\begin{array}{l}10 \text { percentage points higher support } \\
\text { level at the priority axis, } \\
\text { if the total priority axis dedicated to } \\
\text { CLLD by the member countries }\end{array}$ \\
\hline
\end{tabular}


There is also a possibility to use ITI and CLLD not only in the mainstream programs, but in the European Territorial Cooperation operational programmes as well. The new regulation for European Territorial Cooperation ${ }^{31}$ states that intermediate bodies and also European Groupings of Territorial Cooperation (EGTC) can be responsible for managing ITI activities and the Community-led Local Development actions can be implemented also by European Territorial Cooperation programmes.

A Joint Action Plan (JAP) ${ }^{32}$ - which is not a territorial development tool, but as a response to the integrated approach it makes the common use of the funds possible - a part of one or several priority axes or operational programmes implemented by a results-based approach, in order to achieve specific objectives agreed jointly between the Member State and the Commission. The JAP is a tool for simplified cost implementation also ${ }^{33}$ and works like the ITI basically, except that JAP does not allow infrastructure as an eligible activity. JAP is made up of a smartly defined goal and a well-thought intervention logic (the series of projects to be implemented to reach the goals, agreed milestones, outputs and results...) which serve as evidence for the European Commission to allow the using of using simplified cost-mechanisms. A JAP can only be successfull if the intervention logic is sound in the pursuit of goals that are both realistic and ambitious. The implementation of a JAP relies on a special type of financial management and the payment will be linked exclusively to milestones, outputs and results, but it also allows the using of lump sum and standard scale of unit costs to be applied to projects implemented through public procurement and that lump sums are not capped. Accordigly JAP is an option, where the one beneficiary should be a public law body and is supported by ESF, ERDF, CF. The minimum public support should be EUR 10 million or $20 \%$ of the OP (lower figure) or EUR 5 million for 1 pilot/OP. It could be submitted after the start of the OP and there is no specific duration for the JAP, but it is expected to be shorter than the program period.

\footnotetext{
${ }^{31}$ REGULATION (EU) No 1302/2013 OF THE EUROPEAN PARLIAMENT AND OF THE COUNCIL of 17 December 2013 amending Regulation (EC) No 1082/2006 on a European grouping of territorial cooperation (EGTC) as regards the clarification, simplification and improvement of the establishment and functioning of such groupings

${ }^{32}$ CPR Art. 104-109.

${ }^{33}$ CPR Art. 109.
} 
Figure 5 JAP structure (Source: European Commission, Open days 2013)

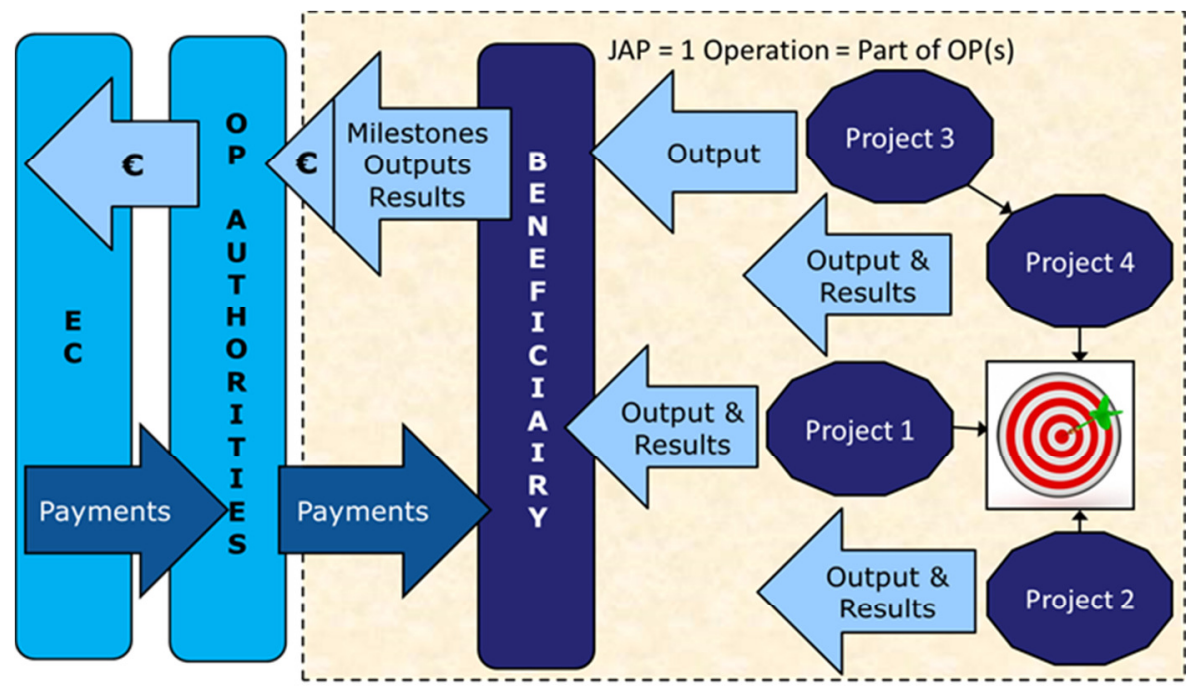

Commission Decision

So in one hand JAP could be a resultoriented and flexible (scope, time period, can be negotiated later) tool for all types of operations with less administrative burden, on the other hand it could mean additional workload to negotiate and follow the JAP, and need different types of management in the same OP.

JESSICA (Joint European Support for Sustainable Investment in City Areas) is also a development tool for complex city investments with the objective of investing cohesion policy sources in a revolving way in urban projects. Under JESSICA it is possible to combine grants, technical assistance and loans in a single financial instrument. Financial instruments are a special category of spending and their success hinges on a correct assessment of market gaps and needs and suitable, well thought-out design. The investment target of JESSICA is financing of revenue generating projects (direct or indirect revenues) with positive economic, social, cultural and environmental impact. However JESSICA enables investments in projects, which can neither qualify for a grant financing nor can be financed on a purely commercial basis. 
Figure 6 Investment targets

Target IRR (Internal Rate of Return)

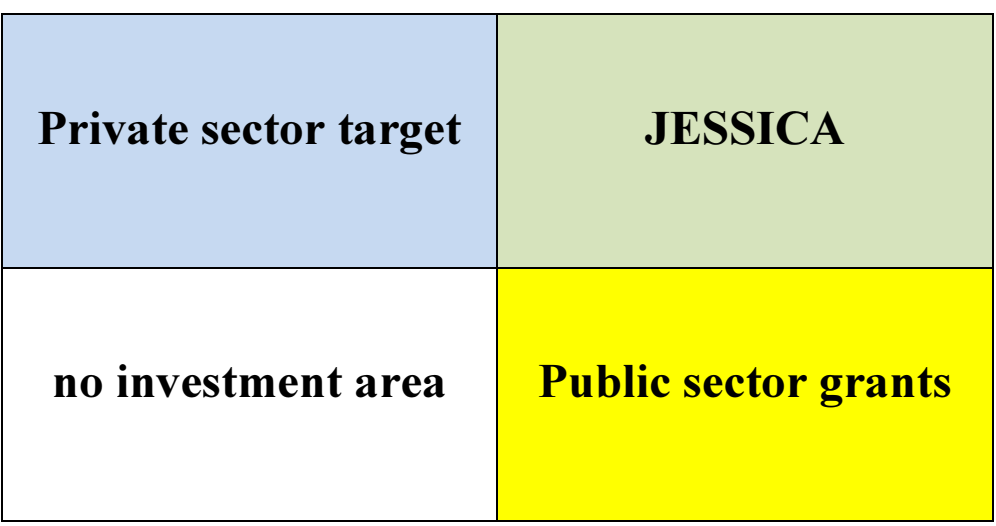

Sustainable ERR

Building on the implementation experiences with financial instruments under shared management in past programming periods and reflecting the importance attached to them in the proposed MFF 2014-2020, the Commission proposes to expand and strengthen the use of financial instruments in the next programming period as a complement to traditional grant-based financing. The CPR enables a better combination of financial instruments with other forms of support in duly justified cases. The CPR aims also at increased flexibility in mobilising support to financial instruments from a variety of sources. It provides that specific requirements are necessary regarding the transfer and management of assets managed by entities to which implementation tasks are entrusted. This will enable contributions to financial instruments from several priority axes or operational programmes and allow a wider range of options for national contributions.

Figure 7 FIs in the next Programming Period (2014-2020)

2007-2013

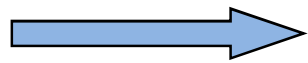

\begin{tabular}{|l|l|}
\hline More sectors & 11 thematic objectives \& priorities foreseen by ESIF Ops \\
\hline More sources & All ESIF fund (ERDF, ESF, Cohesion Fund, EAFRD,EMFF) \\
\hline $\begin{array}{l}\text { More } \\
\text { implementation } \\
\text { options for MAs }\end{array}$ & $\begin{array}{l}\text { Contribution to national or regional EU level FIs under shared management: } \\
\text { - Tailor-made instruments (cf. current period) } \\
\text { - Standardized "off-the-shelf instruments for quick roll-out } \\
\text { Contribution to EU level FIs under central management (ring-fencing) }\end{array}$ \\
\hline More incentives & $\begin{array}{l}\text { EU-level instruments: } \\
- \text { Up to } 100 \% \text { of the paid support may come from ERDF, ESF and CF; separate } \\
\text { priority axis to be foreseen } \\
\text { Instruments implemented at national/regional level: } \\
- \text { ERDF, ESF, CF co-financing rate to increase by 10\% if an entire priority axis } \\
\text { is implemented through FIs }\end{array}$ \\
\hline
\end{tabular}

2014-2020 
As real-world experience has shown sustainable development projects require the participation of diverse stakeholders and perspectives with the ideal of reconciling different and sometimes opposing values and goals. For the decision of what is most needed and what is the best and most effective way promoting economic development and territorial and social cohesion by using public money, the opinion and knowledge of the local, territorial stakeholders are also important. With the decentralized implementation the objectives can be better defined and the development measures may be enjoying the trust and support of local, regional levels. The integrated interventions have to be tailored to the characteristics of the affected areas, because cohesion policy shows significantly less effectiveness where the individual spatial situations and problems cannot be taken into account. But integrated approaches require cooperation across different (administrative, sectoral...etc.) boundaries and with different actors and need appropriate governance structure and capacity building. It is essential to overcome sectoral approaches and to create added value for the participants.

Barriers are generally represented by different policy aims and scope (in the different sectors and at the different levels), lack of harmonization of programmes' implementation, including complex legal and financial rules and eligibility and evaluation criteria, insufficient coordination of responsible authorities at all levels. The different scope is in some cases also translated into different project architectures: centralized national management versus shared management with territorial scope and implementation. Operational barriers may also emerge not only from the application of cohesion policy rules, but from state aid and public procurement rules as well. So, added to the cooperation in-depth knowledge is required for stakeholders to make use of the new tools in an integrated manner.

\section{CONCLUSION}

With the purpose of raising awareness on existing funding sources and on the importance of exploring synergies, it is suggested to improve exploitation of funding opportunities by combining the different sources within the next programming period 2014-2020. This opportunity is supported by some flexibility and must be implemented in a framework of coherent programming, common prioritization and strategic policy coordination. A holistic approach, covering cross-cutting issues, competitiveness and sustainability aspects calls for 
the active and harmonized involvement of all actors and agents at European, national and regional levels.

In light of the above the new territorial development tools are an integrated framework to address common challenges in a given geographical area. So far these methods can prove their added value by improving cooperation mechanisms and tryto adopt a bottomup approach to territorial development in a practical way leading to greater coordination and efficiency of the efforts.

However one of the limitations for using these methods could be an insufficient proactive coordination and interaction between policies at different governance levels, between different actors (ministries and agencies) with divided ownership and operational responsibilities with different priorities and scopes. Despite the fact that the integrated approach clearly requires more effort in terms of planning and implementation as regards time and workload, the result is often that more well-grounded plans can be produced with increased ownership of the objectives of the project.

Although during the previous programming period synergies were to be found only exceptionally, for the next period 2014-2020 and beyond, solid preconditions exist for synergy implementation since all development instruments share the same programming period and the same goals set out under the Europe 2020 Strategy for smart, sustainable and inclusive growth. Common policy planning and priority alignment are major drivers for synergies, leading to greater policy coherence, and allowing better exploitation and leverage of EU funding. At programme level, coordinated implementation of programmes strengthens the partnership in the programme delivery. Thus, facilitating truly integrated programmes and projects requires a shift in attitude, not only towards results and objectives, but less on absorption and expenditure. It also requires a stronger coordination and partnership at all levels between the various stakeholders. Therefore one of the key issues is the appropriate planning and programming ${ }^{34}$. The other one is the common effort to increase the coordination and cooperation between the different stakeholders. It seems that better spending as well as integrated approach by encouraging cooperation between levels and between public and private sectors can be a result of the implementation of the

\footnotetext{
${ }^{34}$ Györgyi Nyikos (2013): Development policy in the age of austerity - result-orientation, effectiveness and sustainability, The 21 st NISPAcee Annual Conference "Regionalisation and Inter-regional Cooperation" May 16-18, 2013 Belgrade, Serbia,
} 
new tools. The decisive point is whether the stakeholders are willing and would cooperate with each other in the implementation or not.

\section{REFERENCES}

Nyikos, G. (2013). The impact of developments implemented from public finances, with special regard to EU cohesion policy, Public Finance Quarterly. Journal of public finance, 2013/2 165-185. pp.

Nyikos, G. (2013). Development policy in the age of austerity - result-orientation, effectiveness and sustainability, The 21st NISPAcee Annual Conference "Regionalisation and Inter-regional Cooperation" May 16-18, 2013 Belgrade, Serbia

European Commission: URBAN DEVELOPMENT IN THE EU: 50 PROJECTS SUPPORTED BY THE EUROPEAN REGIONAL DEVELOPMENT FUND DURING THE 2007-13 PERIOD Final Report March 2013

European Commission: SUSTAINABLE URBAN DEVELOPMENT, Study, 2010.

The European Commission factsheets on COHESION POLICY 2014-2020

REGULATION (EU) No 1303/2013 OF THE EUROPEAN PARLIAMENT AND OF THE COUNCIL of 17 December 2013 laying down common provisions on the European Regional Development Fund, the European Social Fund, the Cohesion Fund, the European Agricultural Fund for Rural Development and the European Maritime and Fisheries Fund and laying down general provisions on the European Regional Development Fund, the European Social Fund, the Cohesion Fund and the European Maritime and Fisheries Fund and repealing Council Regulation (EC) No $1083 / 2006$

REGULATION (EU) No 1301/2013 OF THE EUROPEAN PARLIAMENT AND OF THE COUNCIL of 17 December 2013 on the European Regional Development Fund and on specific provisions concerning the Investment for growth and jobs goal and repealing Regulation (EC) No 1080/2006

REGULATION (EU) No 1304/2013 OF THE EUROPEAN PARLIAMENT AND OF THE COUNCIL of 17 December 2013 on the European Social Fund and repealing Council Regulation (EC) No 1081/2006

REGULATION (EU) No 1300/2013 OF THE EUROPEAN PARLIAMENT AND OF THE COUNCIL of 17 December 2013 on the Cohesion Fund and repealing Council Regulation (EC) No 1084/2006

REGULATION (EU) No 1302/2013 OF THE EUROPEAN PARLIAMENT AND OF THE COUNCIL of 17 December 2013 amending Regulation (EC) No 1082/2006 on a European grouping of territorial cooperation (EGTC) as regards the clarification, simplification and improvement of the establishment and functioning of such groupings

REGULATION (EU) No 1305/2013 OF THE EUROPEAN PARLIAMENT AND OF THE COUNCIL of 17 December 2013 on support for rural development by the European Agricultural Fund for Rural Development (EAFRD) and repealing Council Regulation (EC) No 1698/2005 